I Doutor em antropologia pela Universidade de São Paulo (USP),

São Paulo, SP, Brasil

ricardoteperman@gmail.com

Ricardo Teperman'

\title{
DISSONÂNCIA EM CONCERTO: A INAUGURAÇÃO DA SALA SÃO PAULO
}

Ao dedicar um livro ao tema dos "começos" na literatura, Edward Said destaca que seu interesse é corolário de uma descrença na possibilidade de se localizar um verdadeiro começo. Segundo o autor, o começo é "o primeiro passo na produção intencional de sentido" (Said, I975: 5). ${ }^{\text {I }}$

Neste artigo, ${ }^{2}$ proponho uma análise do concerto de inauguração da Sala São Paulo, em 9 de julho de I999, que entendo ser o principal marco da chamada reestruturação da Orquestra Sinfônica do Estado de São Paulo (Osesp), iniciada após a morte de Eleazar de Carvalho, em setembro de I996. O evento representou ocasião privilegiada para a produção de um "começo"; por isso informa a respeito dos sentidos que os líderes do projeto desejavam atribuir à Osesp e a sua nova sede, bem como permite identificar disputas e outros sentidos em jogo - sentidos não previstos, não desejados, não alinhados.

Construir uma sala de concertos de alto padrão em uma antiga gare ferroviária - a Estação Júlio Prestes -, na qual trens continuam circulando diariamente, foi certamente uma proeza da engenharia, como muito se gabou à época. Texto institucional sobre a construção da sala informa que ela deveria estar "perfeitamente isolada do seu meio ambiente, funcionando como uma caixa totalmente estanque e impermeável a sons e vibrações vindos de fora" (Marco \& Zein, 2007: 44). Tratava-se de erigir um templo para o som disciplinado, em que não só as intervenções do mundo exterior fossem barradas como as reverberações dos sons produzidos no próprio interior fossem direcionadas 
de maneira a produzir os harmônicos esperados. ${ }^{3}$ Daí a imensa laje de concreto, revestida de neoprene, construída sob o anfiteatro para amortecer as vibrações do trem; o sofisticado e silencioso sistema de climatização; e nec plus ultra, as placas móveis do teto, que permitem várias configurações acústicas, conforme o tipo de obra apresentada. 4

Esse tratamento acústico quase laboratorial se apoia na concepção consagrada da música como arte "autônoma", "além do tempo", 5 concepção essa que se vê logo problematizada pelos muitos ancoramentos sociais, locais e históricos mobilizados na ocasião da inauguração da Sala São Paulo.

Discutirei inicialmente a escolha da data da festa e do nome da sala, bem como da obra a ser interpretada, argumentando como o esforço parece ter sido na direção de moldar um projeto de orgulho paulista. A dimensão supostamente elevada, universal e atemporal da música clássica reverberaria no espaço grandioso da sala de concertos, com suas colunas neoclássicas e o tratamento acústico de alto padrão, transmitindo pujança e estabilidade. Por meio de um esforço de reconstrução etnográfica do evento de inauguração - que contou com a presença dos chefes do Poder Executivo municipal, estadual e federal -, discutirei de que maneira vozes dissonantes se fizeram ouvir, revelando a força e as contradições do projeto da orquestra.

\section{COMEÇANDO DO COMEÇO}

A expressão "nova Osesp" teve alguma aderência entre I 997 e I 999 - período que tem no concerto de inauguração da Sala seu evento máximo -, transformando não apenas o futuro, mas também o passado da orquestra, que passou a valorizar simbolicamente sua ancestralidade. Os primeiros concertos da Sinfônica Estadual foram em I953, mas a orquestra só seria criada por lei em I954 - ano que foi referência para as celebrações de aniversário de 50 e 60 anos, em 2004 e 20I4, respectivamente. Era a primeira vez que se celebrava a data da lei de criação da orquestra nesses termos; I964, I974, I984 e I994 haviam passado em brancas nuvens, apesar de o grupo estar em atividade em todas essas ocasiões.

A coincidência com a efeméride de comemoração do Quarto Centenário da cidade de São Paulo, oficialmente fundada em I554, é, sem dúvida, um motivo poderoso para as várias versões do projeto da Osesp, que sempre valorizou a ideia da orquestra como um símbolo paulista (Teperman, 2016).

Falando a respeito de nomeações e inaugurações, a Estação Júlio Prestes (EJP) só recebera o nome atual em I95I, em homenagem ao ex-presidente do estado de São Paulo, ícone dos anos de ouro da economia cafeeira e do orgulho paulista ferido em I930. Até I95 I, a estação era conhecida como Estação Sorocabana (como se pode ler até hoje nas inscrições em concreto no alto do prédio), por ser o último ponto da estrada de ferro de mesmo nome. Durante a reforma da EJP, no final dos anos I990, trabalhou-se com a ideia de batizar o novo espa- 
ço de Sala Júlio Prestes e chegou-se a elaborar um logotipo básico. A opção posterior e definitiva por Sala São Paulo garantia que o nome da capital paulista viajasse o mundo graças à reputação que, esperava-se, o concert hall viria a conquistar.

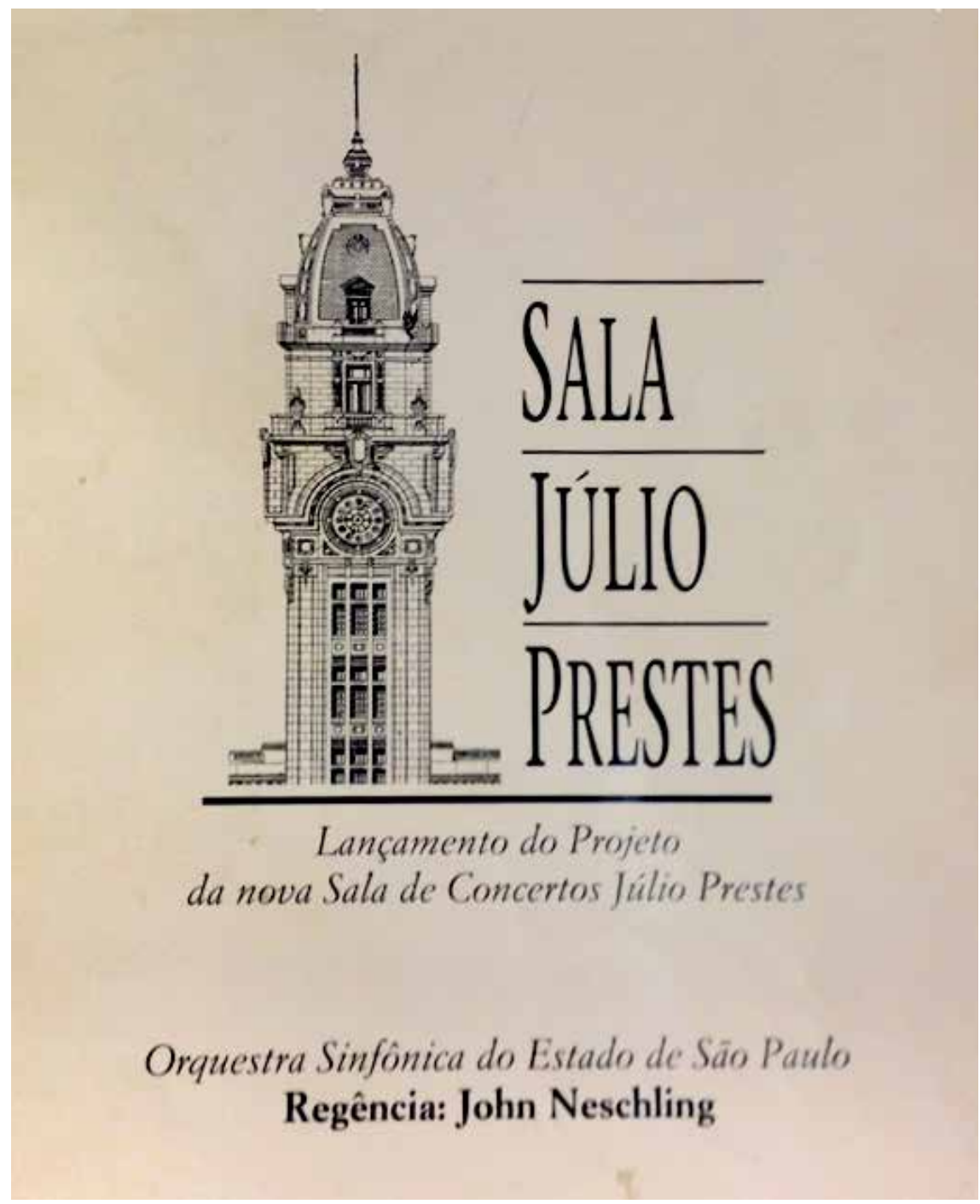

Figura I

Impresso produzido para concerto de I I de março de I 997 
A data para a inauguração da Sala, 9 de julho, também era carregada de sentido, por remeter ao início do levante armado contra o governo de Getúlio Vargas, em I932, quando os sentimentos de pioneirismo, autonomia e superioridade paulistas inspiravam ânimos separatistas. Note-se que o dia 9 de julho havia se tornado feriado estadual em I997, por decreto de Covas.

Vários eventos anteriores ao 9 de julho de 1999 foram apresentados como marcos do recomeço da orquestra: o concerto em I I de março de I997, que anunciava as obras na Estação Júlio Prestes; o concerto de I 2 de setembro de I997, já com o corpo de músicos renovado após audições de seleção, e que foi o primeiro usar a expressão "nova Osesp", uma maneira de se diferenciar de algo que supostamente terminara com a morte, em setembro de I996, de Eleazar de Carvalho - diretor do grupo desde i973. A orquestra regida por Eleazar passou a ser às vezes referida, notadamente pelo maestro John Neschling - principal líder da chamada reestruturação - como "velha Osesp". ${ }^{6}$

\section{MAHLER EM SÃO PAULO: MORTE E RESSURREIÇÃO}

O concerto de inauguração da Sala São Paulo resultou de uma complexa e ambiciosa operação. Definidos data e nome, restava organizar a festa. Como seria a cerimônia? Quem não poderia faltar? A lista de convidados certamente daria trabalho. E seria preciso cuidar bem da repercussão do evento. Que tipo de cobertura de imprensa seria desejável?

Para uma boa festa é preciso também pensar no que servir e, no caso de uma festa de uma orquestra, o que tocar. John Neschling programou a "Sinfonia no 2 - Ressurreição”, de Gustav Mahler.

O subtítulo "Ressurreição" foi exaustivamente explorado pela imprensa à época, pautando a repercussão do evento. De imediato, a ideia de morte e ressurreição estabelece ao mesmo tempo um corte e uma linha de continuidade com relação à história da Osesp. Ruptura na sugestão de que algo havia morrido - só assim poderia ressuscitar -, mas permanência já que se trata do retorno da mesma orquestra, agora transformada. A morte efetiva de Eleazar de Carvalho como que permitiu o aprofundamento da ideia de que a Osesp estava "morta".

Seja na efêmera aparição da orquestra nos anos I950, em sua atuação um pouco mais consequente e longeva na década seguinte, ou mesmo na relativamente bem-sucedida empreitada sob o comando do maestro Eleazar, a experiência do grupo havia sido até então marcada por grande volatilidade. A orquestra patinava em contextos de patente precariedade: poucas escolas de música, poucos instrumentistas bem formados e pouco público, um mercado desorganizado e inativo, com poucas e frágeis instâncias de consagração.

Excepcionalmente densos e produtivos foram os anos em que a orquestra dispôs do Teatro Cultura Artística como sede provisória, entre I977 e I 985. Lá ensaiava e se apresentava regularmente, com temporadas de concertos in- 
cluindo programas que apresentavam recortes propositivos do repertório sinfônico, para um público cativo, e atraindo o interesse da crítica especializada dos principais órgãos de imprensa locais.

A partir de I986, a orquestra enfrentou crescentes dificuldades e não é à toa que um apelido autoderrisório veio substituir o sentido original da sigla Osesp: Orquestra Sinfônica em Sede Provisória (Neschling, 2009). A provisoriedade e a precariedade das instalações físicas da orquestra contribuíam para a deterioração do ambiente de trabalho já prejudicado pelos baixos salários. Com o tempo tomado por várias atividades complementares, os músicos não estudavam suas partes previamente, como é praxe em orquestras sinfônicas profissionais. Os ensaios, que invariavelmente começavam com atraso, eram feitos com muita leitura à primeira vista, o que acarretava erros frequentes.

As dificuldades da orquestra nos anos I99o seriam objeto de discursos cada vez mais lamuriosos por parte dos músicos e maestros que lideraram o processo que chamaram de "reestruturação", com testes de requalificação, mudanças nos salários e nas rotinas de trabalho. Naquele momento, quanto pior se pintasse a orquestra de Eleazar, mais grandiosa pareceria a "nova" Osesp, após a "ressurreição".

A pauperização do campo musical também aparecia como argumento para declarar a morte da vocação "grandiosa" de São Paulo e, por extensão, do Brasil. Em entrevista ao programa Roda Viva, em I6 de março de I998, Neschling afirmou: "A gente quer entrar no Conselho de Segurança da ONU como membro [...] Um país que não tem Orquestra Sinfônica não pode entrar no Conselho de Segurança". A frase era uma variação militarista de um discurso recorrente nos grandes marcos da história da Osesp. Em I954, ano em que a orquestra foi criada por lei, o poeta Guilherme de Almeida, presidente da comissão do Quarto Centenário, declarou que, com os eventos preparados para a efeméride, São Paulo cumpriria "a promessa que há quatro séculos fizera ao mundo de a este revelar o tesouro de seu labor" (Almeida, I954).

De maneira homóloga, o discurso sobre a "degradação" do Centro de São Paulo - presente desde o final da década de I930 - atingiu uma espécie de paroxismo na virada dos anos I990. Em I99I, Henrique Meireles, então presidente do Bank Boston, fundou a Associação Viva o Centro (AVC), que reunia proprietários de imóveis na região com o objetivo declarado de "reverter situações de declínio, de abandono e ameaça para a área urbana" (Viva o Centro, I 993),? onde estão instalados seus associados. A AVC teve papel determinante no projeto de instalação da Osesp em uma sede definitiva na Estação Júlio Prestes - a Sala São Paulo -, incluindo o empréstimo do CNPJ que viabilizaria a captação de recursos para contratação dos técnicos (Teperman, 20I6). ${ }^{8}$ Mas não só: a associação foi responsável pela formulação conceitual que embasaria os discursos oficiais sobre o projeto e deu contribuição importante também na mobilização da rede de apoio de frações influentes da sociedade - empresários, banqueiros, jorna- 
listas, arquitetos, urbanistas, artistas e intelectuais. A atuação da AVC também se marcou por ambivalências: se por um lado "levantava a bandeira da valorização do Centro histórico", por outro colaborava "para a estigmatização junto à opinião pública de uma série de aspectos que passariam a ser veiculados como responsáveis pela degradação da região" (Kara José, 20I0: 3I).

O discurso de que o Centro "está morto" é o pilar a partir do qual a associação se constrói, a começar pelo nome: Viva o Centro. ${ }^{9}$ É esse também o tom de um editorial do Estadão, publicado no dia seguinte à inauguração da Sala São Paulo, intitulado "A ressurreição do Centro", em que o jornal pede que a administração municipal defina um projeto e defina a liderança política "para que o marketing imobiliário se estabeleça e a revitalização da área ganhe força"(A Ressurreição..., I999).

Não é à toa que a metáfora da ressurreição foi tão eficaz. Apresentava uma perspectiva edificante, de superação da morte do velho maestro, da velha orquestra; propunha a recuperação da vocação grandiosa de São Paulo e do Brasil, bem como a revitalização do Centro da cidade.

Até pela reiteração quase obsessiva com que a palavra ressurreição foi utilizada na época da inauguração da Sala São Paulo, é preciso tomar cuidado para que a dimensão simbólica mobilizada pelo subtítulo da obra de Mahler não eclipse outros aspectos que dão sentido à escolha da peça.

\section{MONUMENTALIZAÇÃo}

A "Sinfonia no 2", de Mahler é obra singular por várias razões: a duração acima do comum (quase uma hora e meia de música); o enorme contingente de instrumentistas e cantores que requer; a exploração dos extremos de intensidade (pianíssimos e fortíssimos); a paleta timbrística ampla e pouco convencional; o alargamento das possibilidades do sistema tonal, com incremento do nível de dissonância tolerada e adiamento renovado da resolução (Mahler antecipa vários dos procedimentos que estariam na origem do atonalismo e do dodecafonismo, propostos por Schoenberg alguns anos depois); o programa escatológico ("Morte", "Juízo Final" e "Ressurreição"); o caráter apoteótico do último movimento, sobre o qual vale dedicar um parágrafo.

A orquestração do trecho final inclui sinos e tam-tam, além de dez trompas, seis trompetes e duas harpas, contribuindo para o caráter hiperbólico da música. Motivos diatônicos ascendentes, em direção à tônica, propõem um discurso consagrador. No acorde final, mi bemol maior, Mahler ainda introduz um órgão - o mais potente dos instrumentos -, com a indicação de que seja tocado em registro pleno ("volles Werk - organum plenum"), e pede na partitura que regente e orquestra terminem com a maior intensidade possível ("Mit höchster Kraftentfaltung"). Todos os meios são mobilizados para construir uma experiência musical que tente dar conta do ambicioso programa imaginado por Mahler: “Deus aparece em toda Sua glória, e o Juízo Final é preenchido por seu 
amor onipresente". Segundo o biógrafo Jens Malte Fischer (20 I I: 203), o impacto emocional do último movimento surpreendeu o próprio compositor: "senhores de idade não tinham vergonha de ser vistos chorando, enquanto jovens e mulheres se lançavam desbragadamente uns nos braços dos outros".

A "Sinfonia Ressurreição" é um dos mais eloquentes exemplos de "maximalismo" sinfônico, tendência que orientou parte da produção musical germânica no fin de siècle e no primeiro modernismo, quando os compositores buscavam lidar com questões metafísicas, em diálogo com os avanços da filosofia alemã. ${ }^{\mathrm{Io}}$ As óperas de Richard Wagner e seu ideal de Gesamtkunstwerk [obra de arte total], ${ }^{\text {II }}$ e o ciclo Gurre-Lieder, de Schoenberg, podem ser considerados experiências maximalistas. O próprio Mahler (apud Grange, I973: 424) faz uso do conceito wagneriano, quando menciona sua busca do texto "que vai apoiar a apoteose da "Sinfonia no 2 " e lhe dar significado, formular sua mensagem e fazer dela uma 'obra de arte total'".

É certo que as ambições do compositor eram tudo menos modestas. O finlandês Jean Sibelius relatou uma conversa que teve com Mahler, quando este teria afirmado: "Uma sinfonia deve ser como o mundo. Deve abarcar tudo". ${ }^{\text {I2 }}$ A formulação reaparece em carta à confidente Natalie Bauer-Lechner (apud Fischer, 20I I: 275) - "Para mim, 'sinfonia' significa construir um mundo com todos os recursos técnicos que estejam à disposição” - e é citada repetidamente por críticos e musicólogos, que a exploram em chave interpretativa.

Mahler incluiu na "Ressurreição" várias passagens para banda off-stage - músicos que se posicionam de maneira a fazer com que suas intervenções soem vindas literalmente de fora. O procedimento já fora usado por compositores como Berlioz e Beethoven, em situações dramáticas pontuais (no geral, em peças programáticas), mas em Mahler ganha contornos particulares, se pensarmos no seu conceito de sinfonia como "um mundo". Numa palavra, o compositor reconhecia a existência de um mundo "fora do mundo da sinfonia" e tentava agir sobre ele, ordenando-o.

Regente reputado e exigente, Mahler colocou em suas partituras mais marcas de andamento, intensidade e expressão (e outros tipos de indicação) do que qualquer outro compositor até então. À indicação de andamento do primeiro movimento da "Sinfonia no 2" - "Allegro Maestoso" -, segue-se uma recomendação: "Mit durchaus ernstem und feierlichem Ausdruck" (com expressão bastante séria e solene). Em vez de marcar "adagio", aparecem indicações como "adagissimo" ou "noch langsam" (ainda mais lento). O sinal de expressão para a frase em uníssono das cordas nos primeiros compassos não é apenas fff (fortississimo) - mas "ferozmente".

Essas anotações revelam o desejo que o compositor tinha de controle sobre o resultado de sua música; nas palavras de Adorno (I992: I678), "Mahler buscava alcançar uma composição à prova de falhas". ${ }^{\text {I3 }}$ O compositor inclui ainda longas "notas de rodapé" com orientações cênicas sobre a disposição dos 
músicos (como no quarto movimento "Urlicht", em que pede que os sopros se posicionem uns ao lado dos outros, de preferência no fundo do palco). Todas essas precauções informam também sobre o papel que Mahler atribuía ao regente, como principal responsável para garantir que cada uma dessas marcas fosse interpretada de acordo.

Essa ambição totalizante carrega contradições, como apontou o próprio Adorno (I992: 88): "As obras de arte que [Mahler] criou sonham com a abolição da arte por meio da plenitude que suas sinfonias evocam de maneira infatigável e em tantas variações. Daí a natureza contraditória de sua obra. O clichê do hiato entre intenção e realização não pode ser pensado como uma inadequação estética, mas como a própria inadequação da estética ela mesma".

Para Adorno (I 992), a ideia mahleriana da sinfonia como um mundo é o resultado estético que denuncia a inadequação da estética e devolve a obra de arte para a bagunça do mundo.

A "Sinfonia Ressurreição" lança seus ouvintes em uma experiência desconcertante, que tende a deixá-los ao mesmo tempo subjugados ao "poderio quase avassalador da música" e impedidos de compreender plenamente "esse edifício sonoro que, ao fim de uma hora e pouco de concerto, exibe uma certa ordem e medida". ${ }^{14} \mathrm{~A}$ ambivalência criada por esse monumento ao mesmo tempo edificante e dissonante permitiu que a obra fosse programada nas mais diferentes ocasiões, operando como potencializadora de programas ou projetos pessoais dos regentes, das orquestras e dos teatros, ou de grupos mais ou menos organizados em torno de causas comuns. ${ }^{\text {I5 }}$

Considerando a complexidade rítmica e harmônica da obra, o número de músicos envolvidos e as indicações na partitura, interpretar a "Sinfonia Ressurreição" é uma prova de fogo para o conjunto - com solos de quase todos os instrumentos - e sobretudo para o maestro. Se uma sinfonia de Mozart e até mesmo algumas sinfonias de Beethoven podem ser interpretadas por uma orquestra sem regente, numa sinfonia de Mahler ele é imprescindível. ${ }^{16}$

Pelo grande protagonismo que exigia, a peça contribuía para fortalecer a figura do novo diretor artístico da orquestra. O compositor é uma das especialidades de Neschling, segundo depoimento de vários músicos da Osesp (Teperman, 20I6). Além disso, o próprio maestro mobilizou elementos autobiográficos para explicar a escolha do programa para a inauguração da Sala: "Minha família provém da Europa Central e, vivendo em Viena, foi contemporânea de Mahler. Meu professor ali, o maestro Hans Svarowsky, conheceu Mahler pessoalmente. E foi lá que eu me aprofundei em Mahler e em Strauss" (Moraes, I999).

A escolha da "Sinfonia Ressurreição" para o concerto de inauguração da Sala São Paulo promovia um amplo conjunto e valores e agentes: a monumentalização da música; o arrebatamento do público; a centralidade do regente; a excelência da orquestra. Isso dito, descontadas as particularidades da escolha da "Ressurreição", não há nela nada de cabal. O concerto de 9 de julho foi ape- 
nas o primeiro de centenas que viriam a ocorrer semanalmente na Sala São Paulo desde então. Sua força estava justamente no fato de ser um evento inaugural, um começo, o primeiro passo na produção intencional de sentido: o concerto exemplar, cujas variantes nos anos seguintes aparecerão como desdobramentos ao mesmo tempo singulares e, até certo ponto, intercambiáveis.

\section{COLUNAS NEOCLÁSSICAS E COLUNAS SOCIAIS}

O comentário sobre a obra de Mahler ganha sentido quando se propõe uma reconstrução etnográfica do concerto de 9 de julho, esforço ao qual dedico a segunda parte deste artigo. O fator "monumental" da música era reforçado e amplificado pelas configurações espaciais da Sala São Paulo, e ambas essas dimensões eram elaboradas discursivamente no caderno de notas de programa produzido para a ocasião. Com I6o páginas, em papel couché (em quatro cores), o volume distribuído aos espectadores da Osesp em julho de I999 era a mais extensa e luxuosa publicação já feita pela orquestra - e, considerando esses parâmetros, segue até hoje inigualada. ${ }^{\text {I7 }}$

A fonte utilizada para grafar "Sala São Paulo" na capa do documento reaparece logo nas primeiras páginas, nas cartas do governador e do secretário de Cultura. A solução, que mimetizava caligrafias antigas, prejudicava um pouco a legibilidade e exigia do leitor bem mais esforço do que teria se a fonte tipográfica fosse comum. Mas criava-se um efeito de "carta de fundação" (ver página seguinte), como se fossem documentos históricos de um tempo pregresso.

Os textos eram intercalados com imagens da Sala, destacando suas colunas neoclássicas e seus vitrais. O espírito que orientara a arquitetura de Christiano Stockler das Neves nos anos 1920 - e descrito pelo próprio (apud Marco \& Zein, 200I) como "Luís XVI modernizado" - era também mobilizado pelos autores do livreto, em gesto que reforçava o "classicismo" do evento de música clássica.

A opção pelo preto e branco, o destaque para as colunas coríntias, o close nos ornamentos dos capitéis - as imagens promoviam a entronização da Sala São Paulo como "lugar de culto". No conjunto, os esforços na produção da festa de 9 de julho parecem ir na direção do que Pierre Bourdieu (2006: I4) descreveu como consagração cultural, que "submete os objetos, pessoas e situações que ela toca a uma espécie de promoção ontológica que se assemelha a uma transubstanciação". A formulação tem força desmistificadora, ao propor provocativamente que os efeitos de elevação espiritual suscitados pela escuta da música clássica em ambiente de pé direito elevado e colunas coríntias se expliquem pelo que o gênero representa em termos de dominação social. 


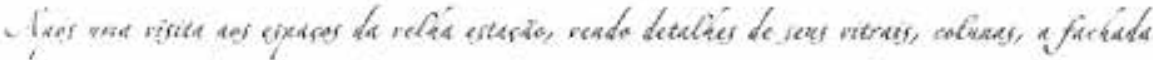

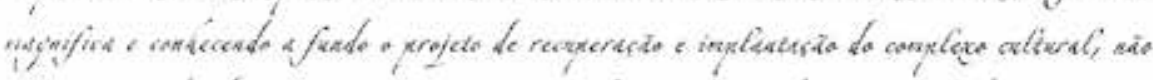

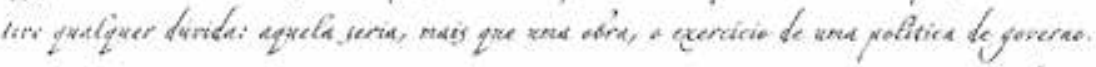

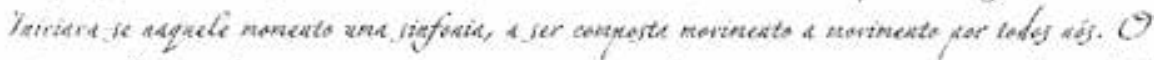

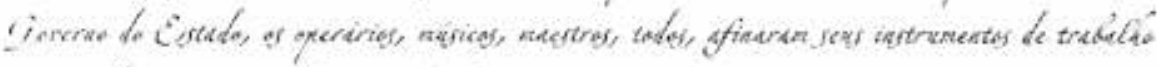

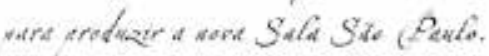

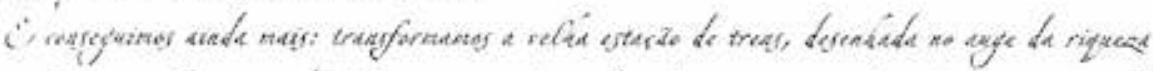

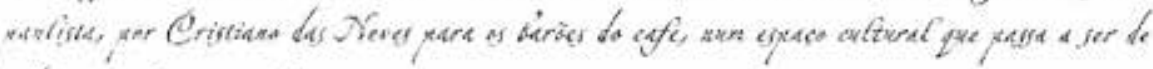

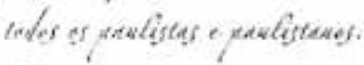

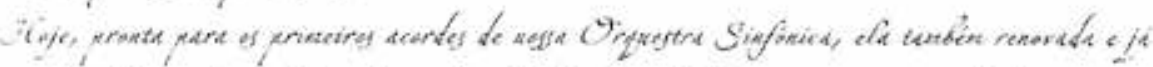

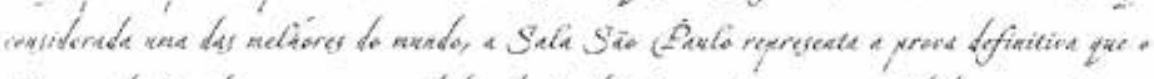

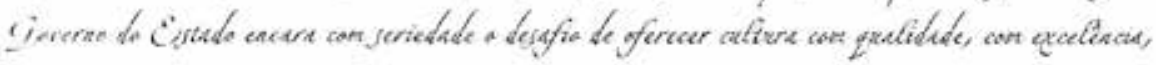

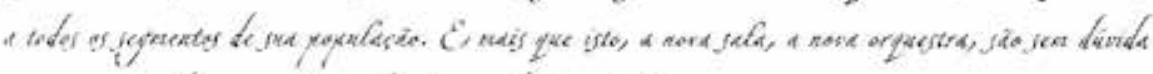

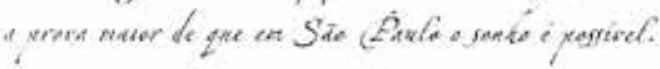



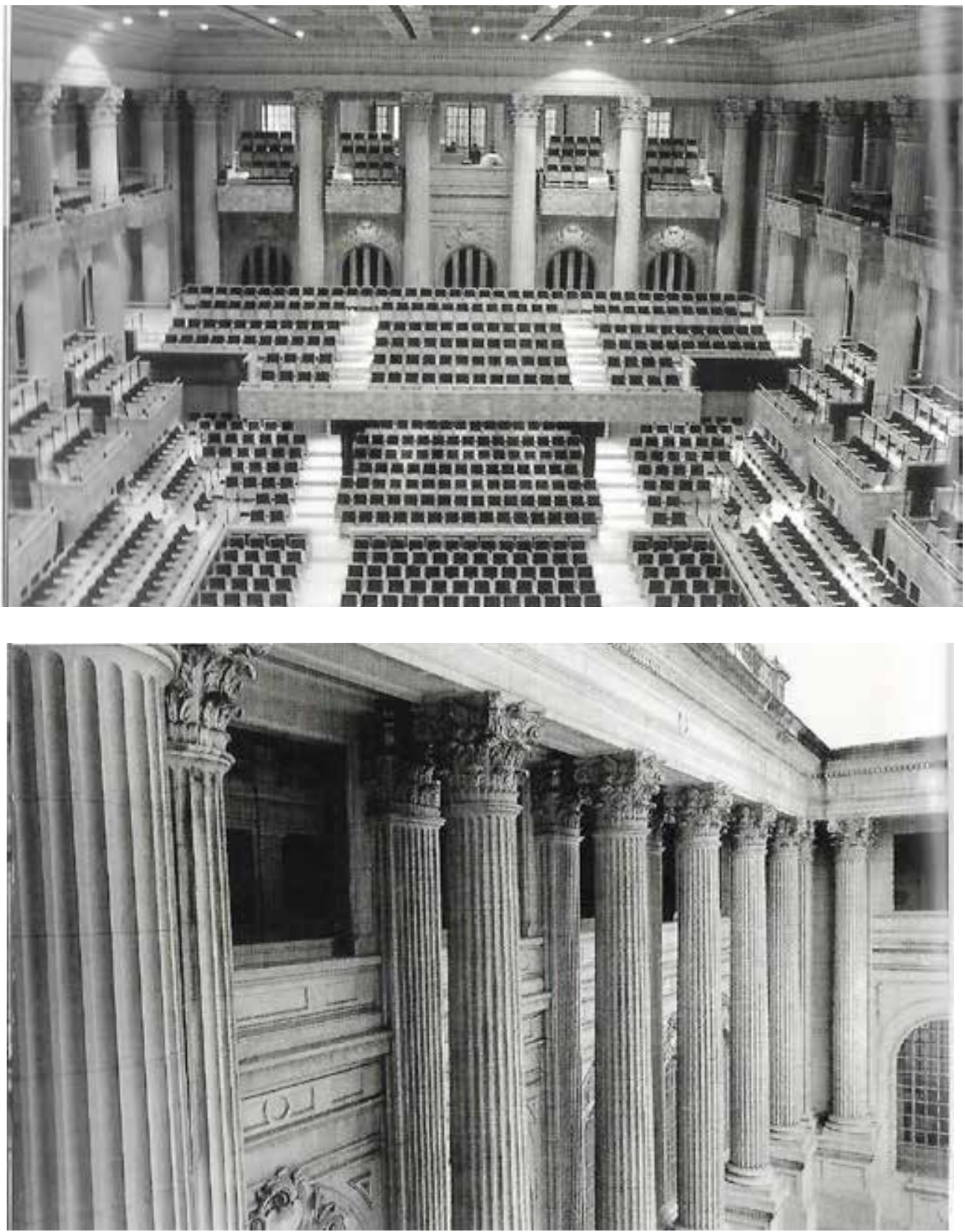

Figura 3

A Sala São Paulo,

em foto de Agnes Melis (I999)

Figura 4

Colunas coríntias na Sala São Paulo,

em foto de Luiz Carlos Felizardo (I999) 
Uma ressalva: não quero reduzir a experiência de apreciação de um concerto sinfônico a uma prática de distinção social nem propor que o projeto de criação da Sala São Paulo e todo o investimento na Osesp se resumam ao aprofundamento do poder simbólico das elites paulistanas. A instalação da orquestra em sua sede trouxe novidades importantes, como o adensamento da vida musical em São Paulo e no Brasil e a relativa democratização do acesso aos concertos, com ingressos a preços muito inferiores aos praticados pelas principais instituições de música clássica da época (Teperman, 20I6).

Isso dito, sem a dimensão mundana é impossível atinar com os sentidos em jogo no processo da chamada reestruturação da Osesp. John Neschling (2009) rememora o sentimento de sucesso quando, em meados de I998, já instalada no recém-reformado Teatro São Pedro, a orquestra passou a contar com cerca de 500 ouvintes em cada uma de suas duas apresentações semanais. Diz o maestro: "A imprensa interessou-se pela novidade e certo dia li, na coluna da Joyce Pascovitch, um comentário sobre um concerto da Osesp. Tratava-se de um comentário mundano sobre o que estava se passando no Teatro São Pedro. Ao perceber que as colunas sociais começavam a divulgar o nosso trabalho, acreditei que estávamos, agora sim, no limiar do sucesso" (Neschling, 2009: I48, grifo meu).

A relevância atribuída por Neschling às colunas sociais, tomadas como índice de sucesso, é reveladora do lugar público que se pretendia e lograva ocupar. Para retomar a formulação do maestro, era importante fazer dos concertos um acontecimento "mundano" - termo que, na definição vernacular proposta por Houaiss (20I5), “caracteriza o mundo ('vida em sociedade') em seus aspectos convencionais e superficiais (formalidades, etiqueta etc.)", especificamente da "sociedade elitizada". Em suma, Neschling destacava e valorizava o fato de que a participação nos concertos da orquestra começava a se tornar objeto de cobiça por setores da elite.

Os conteúdos divulgados nas colunas sociais são de interesse tanto das pessoas retratadas quanto de leitores pertencentes a grupos com menos proeminência social, política, cultural ou econômica e que almejam participar da comunidade de colunáveis. Nos anos seguintes, assuntos da Osesp viriam a ser tratados regularmente nas colunas sociais dos dois principais jornais paulistanos, o que nem sempre gerou impacto positivo para Neschling, uma vez que o espaço também passou a abrigar as disputas de poder e prestígio no interior das elites.

Nenhum concerto, entretanto, voltaria naturalmente a receber tanto destaque quanto o de 9 de julho de I999. A presença do presidente da República exigiu forte esquema de segurança. Na Praça Júlio Prestes, policiais militares faziam um cordão de isolamento até que os convidados, com suas "estolas e casacos de pele em profusão", descessem de seus "carros pretos importados com chofer" (Menezes, I999) e ingressassem numa passarela que os levava da rua até o portão principal da sala, num "desfile de joias inimaginável na região central da cidade" (Bresser, I999). 
O responsável pela lista de convidados foi Osvaldo Martins, secretário de Comunicação, em operação coordenada por Claudio Damasceno, chefe do cerimonial da Secretaria de Estado da Cultura. Covas dera uma instrução com enunciado simples, mas de difícil realização: que todas as cadeiras fossem ocupadas e que nenhum convidado ficasse de fora. Como qualquer organizador de churrasco bem sabe, é impossível ter certeza, até a última hora, quem de fato virá. O protocolo de confirmação RSVP pode, no máximo, amenizar o problema. Christine Starr (2013: 2I2-2 I3), funcionária do Cerimonial do Palácio dos Bandeirantes relata o "trabalhão enorme" que tiveram no "preparo da lista de convidados, envio de convites, confirmação de presenças e recepção dos convidados. [...] Os convites foram enviados com protocolos e muito controlados, pois a procura era grande".

Não haviam sido oferecidos lugares na sala para amigos e familiares dos músicos da orquestra, e essa foi a brecha encontrada por Martins e Damasceno para atender à ordem do governador. Foi instalado um telão no saguão contíguo à sala de concerto, no qual esses convidados ma non troppo poderiam acompanhar o espetáculo, com a deixa de que seriam levados a ocupar eventuais cadeiras vazias no anfiteatro, na ausência dos convidados à vera.

A celebração daquela noite tinha caráter fortemente político e institucional, e não se restringia aos interesses específicos do "mundo da cultura". Tanto que a parte mais importante da cota de convites foi oferecida a figuras da política: ministros, governadores, prefeitos, senadores, deputados federais e estaduais, vereadores, secretários de Estado, representantes do Tribunal de Contas do Estado, do Tribunal de Justiça - todos ou boa parte na companhia de seus cônjuges. Uma fração da sociedade para a qual o dress code do "passeio completo", indicado no convite da inauguração, era pouco diferente da roupa do dia a dia. ${ }^{18}$ Também foram chamados empresários de porte e os cabeças dos principais veículos de comunicação, além de personagens ligados aos vários setores da cultura: teatro, cinema, música, artes plásticas, dança etc.

Não surpreende que o mais completo relato da inauguração da Sala São Paulo publicado nos jornais da época tenha sido feito por um colunista social, Cesar Giobbi, do Estadão. Flavio Moura (I999), repórter do Jornal da Tarde, registrou que as áreas em que os jornalistas podiam circular na EJP "eram restritas, o que dificultava o acesso a quase todos os convidados". Giobbi (I999b) explica que os convidados foram divididos em diferentes categorias: "Quem só tinha convite ficou na plateia. Quem tinha credencial vermelha pôde subir ao andar dos camarotes. Mas para entrar no balcão nobre, ${ }^{19}$ transformado em camarote presidencial, era preciso uma amarela". O registro que o colunista faz da chegada dos convidados é particularmente eloquente:

Pouca gente escapou das vaias dos funcionários do Banespa, na entrada da Estação Júlio Prestes, sexta-feira, na inauguração da Sala São Paulo. Os manifestantes se divertiam, com batucada e apitos, tanto são funcionários públicos com o emprego e o futuro garantidos. Só temem a privatização. Que virá. Bem feito. 
Aplausos só para poucos, como Raul Cortez e Marta e Eduardo Suplicy. Júlio Neves escapou, porque chegou com d. Paulo Evaristo Arns. Sobrou até para Plínio Marcos, que estava tão chique que não foi reconhecido... (Giobbi, I999b)

Como é próprio do formato da coluna social, Giobbi adota sem peias um ponto de vista de "classe", ${ }^{20}$ olhando para o mundo "de cima para baixo". Reportagens de época relatam que havia vários grupos de manifestantes: alguns ligados a organizações estudantis de esquerda; outros a diferentes movimentos de moradia; além dos funcionários do Banespa, que havia sido federalizado e estava em vias de ser privatizado. O colunista prefere dirigir sua crítica a estes últimos que, graças a um suposto futuro garantido ${ }^{2 \mathrm{I}}$ se "divertiam com batucada e apitos", instrumentos de folguedos populares que não teriam lugar nos naipes de uma orquestra sinfônica como a que tocaria em instantes.

A operação é dupla: enfatizar a grandeza do empreendimento cultural (sala de "beleza embasbacante" e "som de primeiro mundo") e passar uma régua nas demandas dissidentes, tornando-as igualmente apolíticas e desimportantes, ao sugerir que os manifestantes são um bando de fanfarrões, a cantar e dançar por diversão.

Em tom irônico, Giobbi alerta que os manifestantes só temem uma coisa: a privatização, para então disparar: "que virá. Bem feito." O viés do comentário não deixa dúvidas sobre o lugar social de onde fala o narrador e sobre o conteúdo ideológico que defende: o "fundamentalismo neoliberal", que marcou o primeiro governo de Fernando Henrique (Sallum Jr., I999) e que, se começava a ser relativizado, ainda era a opinião hegemônica em boa parte do empresariado e da mídia. ${ }^{22}$

O estilo franco do colunista denota a confiança de encontrar cumplicidade no público leitor que, se não estava fisicamente presente na inauguração da Sala, projeta-se como parte dessa vida mundana; uma comunidade de leitores (e potenciais frequentadores de concertos) que compartilha visões e experiências de mundo.

Isso fica ainda mais claro quando Giobbi nota que poucos escaparam das vaias ao entrar na Sala São Paulo. Na leitura do colunista, os convidados comporiam um todo coerente, ${ }^{23}$ em oposição à categoria dos não convidados (e não leitores de coluna social), representados pelos manifestantes. Entre os convidados não vaiados estavam Marta e Eduardo Suplicy, além de d. Paulo Evaristo Arns. O dramaturgo Plínio Marcos foi vaiado mas, segundo Giobbi, por engano - é que estava "surpreendentemente chique". Em suma, a presença de quadros ligados ao PT ou a um imaginário de esquerda era restrita aos de extração quatrocentona, eclesiástica ou desbundada. Se isso emprestava certo verniz republicano ao evento, este estava longe de perder suas tintas amarela e azul - cores do tucano que simboliza o PSDB e que predominam nos acabamentos do mobiliário na sala de concertos (cadeiras e revestimentos de pau-marfim amarelo claro e almofadas azuis). ${ }^{24}$ 
Em se tratando da inauguração de um aparelho cultural público, não surpreende que o evento tenha tido forte viés político e que os organizadores tenham buscado valorizar a gestão à frente da empreitada (e, no embalo, o partido e a coalizão no poder), com descerramento de placa e fotos oficiais. Tampouco surpreende que se tenha tornado palco de manifestações políticas de oposição ("Fora Covas"; "Fora FHC"; "Fora FMI"). Afinal, o início do segundo mandato de Fernando Henrique Cardoso na presidência da República foi marcado por altos índices de impopularidade, em grande parte pela crise de desvalorização do real. ${ }^{25}$ Além do desgaste ligado aos desdobramentos da privatização do Banespa ou às desocupações na região da Luz, o governo do estado enfrentara graves denúncias nas semanas anteriores à inauguração da Sala São Paulo, envolvendo a própria reforma da Estação Júlio Prestes. ${ }^{26}$

Não escapou a nenhum dos jornalistas, e nem mesmo a Giobbi, a percepção das manifestações na entrada da sala como ruído, contrastando com "o som de primeiro mundo" do interior. Para Cassiano Elek Machado (I999), os manifestantes batucavam num "protesto sincopado". Também na Folha, Irineu Franco Perpétuo (I 999) observou: "Os perfumados convidados do concerto fechado da sexta à noite tiveram seus ouvidos poupados da manifestação contra a privatização do Banespa, que ocorria do lado de fora". Giobbi (I999b) não se furta a descrever a "batucada e apitos" com que os manifestantes "se divertiam". Flávio Moura (I999, grifo meu) provoca ainda mais, com um lead irônico: "Vai começar o espetáculo. Regidos por um maestro maltrapilho, os integrantes da orquestra afinam seus instrumentos. São apitos, panelas, tambores, colheres. Segurando faixas, o coro emposta a voz. O maestro dá o sinal, e soam os primeiros acordes dissonantes".

Machado (I999, grifos meus) transcreve a fala de uma manifestante: "Esse teatro é uma palhaçada. Aqui na alameda Nothmann, existe um casarão com I50 famílias e o governo não faz nada. Mas gasta uma fortuna pra fazer espetáculo para eles mesmos". ${ }^{27}$ Ela se referia a um prédio ocupado pela primeira vez em I983 e tornado um cortiço conhecido como "Casarão". Como relata Beatriz Kara José (2007), as negociações para a desocupação do imóvel se estenderam durante anos, sem solução. Um dos "complicantes" era o fato de que as famílias reivindicavam o direito de permanecer na área central, recusando ofertas para que se instalassem em conjuntos habitacionais nas periferias. Em agosto de I995, as famílias foram despejadas, mas o casarão seria ocupado novamente em I997, então integrado ao Fórum de Cortiços e Sem Tetos de São Paulo. Segundo Kara José (2007), algumas famílias que participaram da nova ocupação haviam sido vítimas dos despejos nas imediações do Teatro São Pedro - na ocasião da obra que permitira ali a instalação provisória da Osesp (Teperman, 20I6). A reintegração de posse seria executada em 200I, para que o imóvel passasse a abrigar o Museu da Energia - mais um edifício histórico transformado em equipamento cultural para servir como "âncora para a requalifi- 
cação urbana ao seu redor, além de polo de atração da cultura mundial" (Muarrek, I997), como defendiam certos urbanistas com grande influência na formatação dos discursos dos líderes da Secretaria de Cultura à época, e notadamente a Associação Viva o Centro. ${ }^{28}$

Dois dias após a inauguração da Sala São Paulo, uma reportagem da Folha de S. Paulo notifica que os usuários de crack que costumavam povoar a região da Luz haviam "sumido". Um tenente-coronel da PM entrevistado declarou: "Durante duas semanas tivemos a preocupação de fazer uma varredura em toda a área para minimizar o problema [...] Há estudos para retirada dos travestis, também" (Menezes, I999, grifo meu). O policial sinalizava ainda que a "varredura" em hotéis e bares iria continuar. Pelo tom de suas afirmações, fica claro como ele havia incorporado a essência do discurso urbanístico em voga: "A tendência é que com a inauguração do teatro melhore o nível da região, que está tomada por esse tipo de pessoas" (Menezes, I999, grifos meus).

A aposta numa idealizada capacidade purificadora da música clássica aparece como contraface dessa política higienista. Como se a música clássica tivesse o poder de transformar jovens negros e pobres, viciados em crack, em distintos melômanos de cabelos brancos e hábitos refinados. É como se esperassem que a Osesp, instalada na Sala São Paulo, pudesse funcionar como um flautista de Hamelin às avessas, atraindo legiões de pessoas ricas e supostamente cultas, que fariam da Luz um bairro ilustrado, enquanto os "ratos" eram enxotados pela polícia.

No âmbito deste artigo, basta ressaltar o fato de que o esforço de despolitização que se nota no relato de Giobbi mostra seus limites diante da estridência das vozes dissonantes do lado de fora da Sala.

Mahler ambicionava fazer uma sinfonia "do tamanho do mundo", que trouxesse o mundo para dentro da música. A fanfarra tocando de fora da sala de concertos na "Sinfonia Ressurreição" é apenas o recurso estético mais eloquente a respeito desse programa totalizante. O fato de que em 9 de julho de I 999 houvesse outra fanfarra além da fanfarra de Mahler - a dos manifestantes - faz pensar se não seria sempre assim. A música na sala de concertos está constantemente ameaçada pelos ruídos da cidade, e é só nessa relação tensa que podem ser descortinados os sentidos de uma performance musical - que é também uma performance social.

Irineu Franco Perpétuo (I999), crítico da Folha destacado para cobrir o concerto de 9 de julho, registrou que "o momento mais intimista da sinfonia (o solo de trompa em eco no último movimento) foi destroçado pelo matraquear de um walkie-talkie". O mundo "fora" da música é mais barulhento do que Mahler - ou qualquer compositor ou regente - poderia prever.

O mundo estava fora da Sala, apitando e batendo panela ou fumando crack; estava também na plateia, dividido em crachás amarelos, verdes e vermelhos; e, claro, no palco, com mais de 200 músicos (sem falar na fanfarra no 
backstage). Os ruídos e contradições de São Paulo estavam e permaneceriam, dentro e fora da sala, em todos e em cada um dos concertos que a Osesp apresentou desde então, por melhor que fosse o isolamento acústico da sala, por mais enlevados que tenham se sentido músicos e espectadores, por mais que as notas de programa falassem em forma-sonata, modulações harmônicas, mudanças de compasso, Viena, Paris.

Recebido em I9/I/20I7 | Revisto em Io/9/20I7 | Aprovado em I I/9/20I7

Ricardo Teperman é doutor em antropologia pela USP, editor na Companhia das Letras e editor executivo de Novos Estudos Cebrap. É autor do livro Se liga no som - as transformações do rap no Brasil (20I5). 


\section{NOTAS}

I Lembro ainda os vários historiadores que tomam o problema da produção coletiva de um começo ou de uma tradição. Ver Connerton (I999), Hobsbawn (I984) e Starobinski (I989).

2 Este artigo apresenta parte dos resultados da tese de doutorado defendida em 20I6, na Faculdade de Filosofia, Letras e Ciências Humanas da Universidade de São Paulo (FFLCH-USP), com o título Concerto e desconcerto - um estudo antropológico da Osesp na inauguração da Sala São Paulo. Uma versão preliminar deste artigo foi apresentada no SPG I5 - Intelectuais, cultura e política, organizado pelos professores Lidiane Soares Rodrigues e Alexandre Bergamo, durante o 40 encontro anual da Anpocs, em 2016. Agradeço a Sergio Miceli, comentador na ocasião, bem como aos organizadores do SPG I5. Também agradeço aos pareceristas de Sociologia \& Antropologia os comentários.

3 José Miguel Wisnik (I999: 42) traz reflexões valiosas sobre a sala de concertos como simulacro de câmara anecoica: "A inviolabilidade da partitura escrita, o horror ao erro, o uso exclusivo de instrumentos melódicos afinados, o silêncio exigido à plateia, tudo faz ouvir a música erudita tradicional como representação do drama sonoro das alturas melódico-harmônicas no interior de uma câmara de silêncio onde o ruído estaria idealmente excluído (o teatro de concerto burguês veio a ser essa câmara de representação)".

4 Como discuto em Teperman (20I6), mais do que uma decisão baseada apenas em critérios acústicos, a opção pelo forro móvel foi decorrente do desejo de preservar a visibilidade dos dois pavimentos superiores e de seus vitrais (Marco \& Zein, 2007).

5 A pedra de toque do conceito de autonomia da música talvez seja a resenha feita por E.T.A. Hoffmann para a "Quinta Sinfonia", de Beethoven, publicada pela primeira vez em julho de i8ıo, no célebre Allgemeine Musikalische Zeitung. Nesse breve texto, Hoffmann defende a música instrumental (por oposição à música cantada, que conta com associação da poesia) como a única que pode ser considerada uma "arte autônoma" - e mais, a única arte propriamente romântica, pois tem "como único objeto a ex- 
pressão do infinito" (Locke \& Hoffmann, I9ı7: I27). Além de propor a ideia de que a música apresenta ao ser humano um "reino desconhecido", que nada tem a ver com o "mundo sensual" que nos rodeia, o autor fundamenta sua análise no rigor estrutural da composição, como a destacar sua autossuficiência hermenêutica: tudo o que há para se entender sobre a obra está na própria obra.

6 Ao assumir a direção, em 1973, da então chamada Orquestra Sinfônica Estadual, Eleazar de Carvalho também representara (e se fizera representar) como uma novidade em relação às experiências pregressas do conjunto. Em I983, o maestro organizou uma série de concertos em comemoração ao "décimo aniversário" da Osesp; em I993, repetiu a dose, na comemoração dos "20 anos".

7 Note-se que os termos em que se dava o debate sobre a Luz são em grande medida os mesmos que de maneira geral pautavam a discussão sobre a revitalização do Centro. Ver Frúgoli Jr. (2006).

8 Cerca de ı०\% dos custos da reforma da EJP para a criação da Sala São Paulo foram captados via Lei Rouanet. As empresas envolvidas foram Telefônica, Nossa Caixa e Bank Boston, além da AES Eletropaulo (Teperman, 20I6).

9 No campo oposto, vale destacar a criação, já nos anos 2000, do Fórum Centro Vivo, reunindo dezenas de grupos de diferentes áreas de atuação: movimentos sociais, pastorais, estudantes e professores universitários, organizações não governamentais e grupos de educação, arte e mídia independente. O coletivo tinha como norte ações e discussões a respeito do direito das pessoas pobres de permanecer no Centro e foi criado em reação à hegemonia das pautas propostas pela Associação Viva o Centro (como fica claro na própria escolha do nome).

Io Lembre-se de que, para Adorno (I992: Ior6), “desde Kant e Beethoven a filosofia e a música alemãs se tornaram um único sistema". Sobre os interesses literários e filosóficos de Mahler, ver também Solvik (2007) e Fischer (20I I). Adorno (I992: 84 também comenta o fato de que Debussy tenha ostensivamente abandonado a sala durante a estreia parisiense da "Sinfonia no 2": "Ele ficou chocado pelo que lhe pareceu uma monstruosidade de dimensões infladas se medida pelos critérios da clareza e da distinção". O próprio 
Mahler só superou a duração da "Segunda" uma vez, justamente na sinfonia seguinte, de número 3 (com dez minutos a mais). Vale notar ainda que, com a "Oitava", apelidada de "Sinfonia dos Mil", o compositor superou a "Segunda" no número de músicos participantes. Ver ainda Almeida (2007) e Schorske (I98I; I982). O etnomusicólogo Bruno Nettl (I989) ironiza o fato de que "o conceito de valor musical na tradição artística do Ocidente seja associado de maneira íntima a tamanho. Usa-se a palavra 'grande' como sinônimo de excelente. Um estudante de composição que esteja em busca de um título acadêmico de relevo deve, via de regra, apresentar uma peça 'grande', longa e para grande formação".

I I Richard Wagner decretou que o ciclo da música sinfônica estava encerrado: seu conceito de Gesamtkunstwerk só permitia a criação de dramas musicais, para usar a expressão consagrada por Carl Dahlhaus. Na formulação de Gartenberg (1978: 225), Mahler tomou a ideia wagneriana de Gesamtkunstwerk e a aplicou às sinfonias, gênero que o compositor de óperas considerava morto.

I 2 "Die Symphonie muss sein wie die Welt. Sie muss alles umfassen" (Mahler apud Lebrecht, I988: 218).

I3 Várias observações de comentadores reforçam esse aspecto. "Mahler não deixou nada para a decisão dos intérpretes, que ele acreditava terem uma tendência para o desleixo" (Barham, 2007). E o próprio compositor afirmou em carta a Natalie Bauer-Lechner (apud Revers, 2007): "Exijo que tudo seja escutado da maneira como soa no meu ouvido interno. Para alcançar isso, exploro ao máximo todos os meios disponíveis".

I4 Reaproveito aqui as formulações de Samuel Titan Jr. (20II) a respeito da "Nona Sinfonia", de Beethoven, peça frequentemente comparada com a "Segunda Sinfonia", de Mahler. Sobre essa comparação, ver Taruskin (2010).

I5 O próprio Mahler escolheu sua "Sinfonia no 2 em Dó Menor", composta entre I888 e I894, para o concerto de despedida de sua atuação como diretor da Ópera de Viena, em 1907. Em 24 de novembro de 1963, Leonard Bernstein regeu a "Sinfonia no 2 " em um concerto televisionado em tributo ao presidente John F. Kennedy, assassinado dois dias antes. Em setembro de 20II, por ocasião dos dez anos 
do ataque às torres gêmeas, a Filarmônica de Nova York programou a mesma peça. Em I997, John Neschling havia regido a "Sinfonia no 2", de Gustav Mahler, por ocasião da reabertura do Teatro Massimo de Palermo, na Sicília, do qual era diretor artístico.

I6 Adorno (2009: 225) é um dos autores que observaram a transferência gradual de responsabilidade ao maestro: "No fim do século XIX, a relevância do regente de orquestra aumenta em proporção à complexidade das obras".

I7 O caderno traz também textos introdutórios de John Neschling, Claudia Toni (diretora executiva da orquestra) e Russell Johnson, presidente da Artec, empresa de engenharia norte-americana responsável pelo projeto acústico da sala, além de notas de programa, biografias dos regentes e solistas, e, ao final, fotos de todos os músicos e funcionários da Osesp.

I8 Terno e gravata é o figurino cotidiano de políticos e grandes empresários. No caso das mulheres é que o dress code "passeio completo" gera maior expectativa, aliás como mostram as reportagens da época, que destacam justamente as roupas, joias e adereços. Os músicos de orquestra costumam seguir um código de vestimenta estrito, definido por regimento. O inusual aqui é o estabelecimento de dress code para os convidados, procedimento que se repetiria em efemérides, como nos concertos de comemoração do aniversário da orquestra (60 anos em 20I4, por exemplo).

I9 Trata-se da área hoje denominada "balcão mezanino".

20 Uso aqui a categoria classe social de maneira larga, entendida como "grupo social definido, de um lado, pela quantidade de riqueza apropriada e, de outro, por três dimensões de identidade: temporal, cultural e coletiva". Baseio-me no breve balanço sobre o tema realizado por André Singer (2012), que cita a definição acima, originalmente formulada pelo sociólogo Louis Chauvel, e que constitui um esforço para aproveitar contribuições tanto da tradição marxista quanto da tradição weberiana.

2I Subentende-se que Giobbi fazia menção ao direito à aposentadoria como funcionários públicos, e que este seria menos legítimo do que um futuro garantido pela propriedade e pela renda. 
22 Sallum Jr. sugere que a manutenção do fundamentalismo neoliberal no primeiro mandato de FHC foi uma decisão estratégica para assegurar o controle sobre o sistema político. Para o autor, havia indícios de que o segundo mandato teria viés "liberal-desenvolvimentista". Diz Sallum Jr. (I999: 42): "Quanto mais o governo dispõe de prestígio político, menos necessidade tem de recorrer à distribuição de recursos específicos, no estilo clientelista. Na arena da influência, onde Fernando Henrique podia obter parte desse prestígio político para si e para seu programa, sua posição também era muito favorável. Os órgãos de comunicação de massa e a maioria dos "formadores de opinião" já aderira, há bastante tempo, à perspectiva mais liberal e internacionalizante que orientava o novo bloco hegemônico. Em especial, o próprio presidente da República era apresentado de forma extraordinariamente favorável". Marcos Nobre (2013: 67) defende que é "ambíguo o adjetivo 'neoliberal' quando aplicado ao período FHC", mas sua ênfase é no fato de que o Plano Real e o projeto de estabilização econômica se alinhavam com o modo neoliberal de colocar-se na "lógica do inevitável" (p. 7I). Ver também Arbix (2002) e Nobre \& Torres Freire (I998).

23 Reúno a seguir os convidados citados por Giobbi (I999b): Raul Cortez (ator), Marta Suplicy (ex-deputada federal e candidata derrotada ao governo do estado pelo PT), Eduardo Suplicy (senador), Júlio Neves (arquiteto), d. Paulo Evaristo Arns (cardeal), Plínio Marcos (dramaturgo), Carmo Sodré Mineiro (conselheira do Comunidade Solidária, ver nota abaixo), Wagner Ibrahim (médico, ver nota abaixo), Mario Covas e Lila Covas (governador do estado de São Paulo e primeira-dama), John Neschling (maestro da Osesp), Fernando Henrique Cardoso e Ruth Cardoso (presidente da República e primeira-dama), família Fasano (donos de restaurantes), José Serra e Mônica Serra (ministro da Saúde e esposa), Horácio Lafer Piva (presidente da Fiesp), Emerson Kapaz (deputado federal) e sua esposa Laura [Janina Hosiasson] (professora universitária), Fabrizio Fasano, Pedro Piva (senador) e sua esposa Silvia, Francisco Weffort (ministro da Cultura), Marcos Mendonça e Lucia Mendonça (secretário de Cultura e esposa), Tasso Jereissati e Renata Jereissati (governador do Ceará pelo PSDB e primeira-da- 
ma), Dante de Oliveira (governador do Mato Grosso pelo PSDB), Maria Helena Gregori (esposa do ministro da Justiça, José Gregori), Celso Pitta e Nicéa Pitta (prefeito e primeiradama de São Paulo), Pimenta da Veiga (ministro das Comunicações), Claudia Costin (ministra da Administração e da Reforma do Estado).

24 Agradeço a Elisa Kluger a observação. No livro que documenta a reforma da Estação Júlio Prestes, a opção é justificada pela "resistência ao requinte, que denotaria excesso, mas não necessariamente ao refinamento - que implica em reflexão e aperfeiçoamento, ou ainda busca de certa pureza química. Dentro da sala, a paleta é restrita e as cores são poucas, talvez apenas uma: o azul profundo que impregna a maioria dos detalhes, enquanto a madeira clara faz o discreto jogo de aspiração a um dourado ausente, compondo com o branco marmóreo dos estuques pré-existentes" (Marco \& Zein, 200I).

25 Entre junho de 1998 e junho de I999, o dólar passou de R \$ I,I6 a R \$ I,78 (dados disponíveis em www.bcb.gov.br), e as taxas de juros atingiram astronômicos $45 \%$ ao ano, "na tentativa de conter pressões inflacionárias" (Juro básico, I999). Em 2003, após encostar nos R \$ 4,00, o dólar se estabilizou na casa dos $\mathrm{R} \$ 3,00$. Sobre a crise da desvalorização do real, ver Nobre (2013). Sobre compra de votos para a reeleição, ver Rodrigues (I997).

26 O consórcio formado pelas construtoras Triunfo e Acciona venceu a concorrência para as obras de restauro, reforma e adequações da Estação Júlio Prestes, sendo contratado em outubro de 1997. Em março de I998, o consórcio solicitou à Secretaria de Cultura a inclusão de uma terceira empresa, a Spenco Engenharia e Construção, obtendo decisão favorável. Meses depois, o caso geraria polêmica, uma vez que a Spenco era de propriedade dos mesmos sócios da Construtécnica, a principal doadora da campanha de Covas, e não poderia ter sido aceita no consórcio por ser concordatária desde I994, o que é ilegal segundo a lei de licitações (lei 8.666, art. 3). O principal agravante era o fato de que a Spenco e a Construtécnica eram responsáveis por seis obras de vulto da Secretaria de Cultura: Estúdios Vera Cruz, Teatro São Pedro, Arquivo Histórico do Estado e Bolsa do Café, além da reforma do 
antigo prédio do Dops (sobre a qual falarei a seguir) e da própria reforma da EJP. Após reportagem na Folha de $S$. Paulo (Carvalho, I999), a Secretaria de Cultura distribuiu release à imprensa oferecendo explicações e pareceres de vários juristas a respeito da legalidade da inclusão da Spenco. O caso saiu dos holofotes sem que tenha sido plenamente esclarecido. Malgrado sucessivos e-mails à assessoria de comunicação da Triunfo Participações e Investimentos ao longo de 20I6, não obtive retorno positivo para minha solicitação de entrevista com o engenheiro João Villar Garcia, responsável pelas obras na EJP.

27 Há controvérsia quanto ao número de famílias que ocupavam o casarão. A própria reportagem de Machado (I999) fala em I43. Kara José (2007) fala em "mais de cem".

28 Discuto a questão em Teperman (2016).

\section{REFERÊNCIAS BIBLIOGRÁFICAS}

Adorno, Theodor. (2009). Introdução à sociologia da música. São Paulo: Ed. Unesp.

Adorno, Theodor. (I992). Mahler: a musical physiognomy. Chicago: University of Chicago Press.

Almeida, Guilherme de (1954). Carta de Guilherme de Almeida: presidente da Comissão do IV Centenário. IV Centenário de São Paulo: Especial Memória. Disponível em <http://www.abril.com.br/especial450/materias/abre/ fotor.html>. Acesso em I4 set. 2015.

Almeida, Jorge de. (2007). Crítica dialética em Theodor Adorno: música e verdade nos anos vinte. São Paulo: Ateliê.

Arbix, Glauco. (2002). Da liberalização cega dos anos 90 à construção estratégica do desenvolvimento. Tempo Social, I4/I, p. I-I7.

A ressurreição do Centro (I999). O Estado de S. Paulo, Editorial.

Barham, Jeremy (org.). (2007). The Cambridge companion to Mahler. New York: Cambridge University Press.

Bresser, Deborah. (1999). Joias e vaias no foco de todas as lentes. Jornal da Tarde, São Paulo. 
Bourdieu, Pierre. (2006). A distinção: crítica social do julgamento. Porto Alegre: Zouk.

Carvalho, Mario Cezar. (1999). Empreiteira monopoliza obras da cultura. Folha de S. Paulo.

Connerton, Paul. (1999). Como as sociedades recordam. Oeiras: Celta.

Fischer, Jens Malter. (20I I). Gustav Mahler. Cornwall: Yale University Press.

Frúgoli Jr., Heitor. (2006). Centralidade em São Paulo: trajetórias, conflitos e negociações na metrópole. São Paulo: Edusp.

Gartenberg, Egon. (1978). Mahler: the man and his music. London: Schrimer.

Giobbi, César. (I999a). Batuta viajante. O Estado de S. Paulo. Giobbi, César. (I999b). Um presente de Covas. O Estado de S. Paulo.

Giobbi, César. (I999c). Sem camelôs. O Estado de S. Paulo. Grange, Henry Louis de la. (1973) Gustav Mahler: chronique d'une vie. Paris: Fayard.

Hobsbawn, Eric. (1984). A invenção das tradições. Rio de Janeiro: Paz e Terra.

Houaiss, Antônio. (2015). Dicionário Eletrônico Houaiss da Língua Portuguesa. São Paulo: Objetiva.

Inauguração da Sala São Paulo. (I999). Vídeo, TV Cultura. Juro básico sobe de $39 \%$ para $45 \%$ ao ano. (I999). Folha de S. Paulo.

Kara José, Beatriz. (2010). A popularização do Centro de São Paulo: um estudo de transformações ocorridas nos últimos 20 anos. Tese de Doutorado. Faculdade de Arquitetura e Urbanismo/Universidade de São Paulo.

Kara José, Beatriz. (2007). Políticas culturais e negócios urbanos: a instrumentalização da cultura na revalorização do Centro de São Paulo (1975-2000). São Paulo: Annablume.

Lebrecht, Norman. (I988). Mahler remembered. New York: W. W. Norton.

Locke, Arthur Ware \& Hoffmann, E.T.A. (I9I7). Beethoven's instrumental music: translated from E. T. A. Hoffmann's "Kreisleriana" with an introductory note. The Musical Quarterly, 3/I, p. I23-I33. 
Machado, Cassiano Elek. (I999). Inauguração atrai do presidente ao pipoqueiro. Folha de S. Paulo.

Marco, Anita Regina Di \& Zein, Ruth Verde. (2007). Sala São Paulo: a arquitetura da música. São Paulo: Alter Market. Marco, Anita Regina Di \& Zein, Ruth Verde. (200I). Sala São Paulo de Concertos: revitalização da Estação Júlio Prestes: o projeto arquitetônico. São Paulo: Alter Market.

Menezes, Cynara. (I999). "Polícia 'limpou' área para inauguração”. Folha de S. Paulo.

Moraes, J. Jota. (I999). Entrevista com John Neschling. Jornal da Tarde, São Paulo.

Moura, Flavio. (I999). Sala São Paulo: esse monumento agora é do público. Jornal da Tarde, São Paulo.

Muarrek, Ubiratan. (1997). Cultura âncora. Jornal da Tarde, São Paulo.

Neschling, John. (2009). Música mundana. Rio de Janeiro: Rocco.

Nettl, Bruno. (1989). Mozart and the ethnomusicological study of Western culture (an essay in four movements). Yearbook for Traditional Music, 2I, P. I-I6.

Nobre, Marcos. (2013). Imobilismo em movimento: da abertura democrática ao governo Dilma. São Paulo: Companhia das Letras.

Nobre, Marcos \& Torres Freire, Vinicius. (I998). Política difícil, estabilização imperfeita: os anos FHC. Novos Estudos - Cebrap, 5I, p. I23-I47.

Perpétuo, Irineu Franco. (I999). Primeira regência foi enérgica. Folha de S. Paulo.

Revers, Peter. (2007). Song and song-symphony (I). Des Knaben Wunderhorn and the Second, Third and Fourth Symphonies: music of heaven and Earth. In: Barham, Jeremy (org.). The Cambridge Companion to Mahler. New York: Cambridge University Press.

Rodrigues, Fernando. (I997). Deputado conta que votou pela reeleição por R 200 mil. Folha de S. Paulo.

Said, Edward. (1975). Beginnings. New York: Columbia University Press.

Sallum Jr., Brasilio. (I999). O Brasil sob Cardoso: neoliberalismo e desenvolvimentismo. Tempo Social,I I/2, p. 23-47. 
Schorske, Carl E. (I982). Mahler and Klimt: social experience and artistic evolution. Daedalus, III/3, Representations and Realities, p. 29-50.

Schorske, Carl E. (I98I) Fin de siècle Vienna: politics and culture. New York: Vintage.

Singer, André. (2012). Os sentidos do lulismo: reforma gradual e pacto conservador. São Paulo: Companhia das Letras.

Solvik, Morten. (2007). The literary and philosophical worlds of Gustav Mahler. In: Barham, Jeremy (org.). The Cambridge companion to Mahler. New York: Cambridge University Press.

Starobinski, Jean. (1989). I789: os emblemas da razão. São Paulo: Companhia das Letras.

Starr, Christine. (2013). Os bastidores do palácio. São Paulo: Edição do Autor.

Taruskin, Richard. (2010). The Oxford history of Western music. London/Oxford: Oxford University Press.

Teperman, Ricardo. (20I6). Concerto e desconcerto - um estudo antropológico da Osesp na inauguração da Sala São Paulo. Tese de Doutorado. PPGAS/Universidade de São Paulo.

Titan Jr., Samuel. (20II). Memória e antecipação: a "Nona Sinfonia" de Beethoven. Revista Osesp.

Viva o Centro. (I993). Associação Viva o Centro. Documento I.

Wisnik, José Miguel. (I999). O som e o sentido: uma outra história das músicas. São Paulo: Companhia das Letras. 


\section{DISSONÂNCIA EM CONCERTO: A INAUGURAÇÃO}

DA SALA SÃO PAULO

Resumo

Neste artigo proponho uma análise do concerto de inauguração da Sala São Paulo, em 9 de julho de I999, evento que entendo ser o principal marco da chamada reestruturação da Orquestra Sinfônica do Estado de São Paulo (Osesp), iniciada após a morte de Eleazar de Carvalho, em setembro de i996. A escolha da data da inauguração (9 de julho) e do nome do concert hall (Sala São Paulo) são alguns dos muitos índices que revelam o sentido de um projeto de orgulho paulista, em que os conflitos e contradições da experiência social seriam borrados pela a dimensão supostamente universal e atemporal da música clássica. Por meio de um esforço de reconstrução de tipo etnográfico do evento de inauguração, discuto de que maneira vozes dissonantes se fizeram ouvir, revelando as contradições do projeto da orquestra.

\section{DISSONANCE IN CONCERT: THE OPENING OF} THE SALA SÃO PAULO
Palavras-chave

Música clássica; orquestras sinfônicas;

Osesp;

Sala São Paulo; etnografia.

\section{Keywords}

Classical music; symphony orchestras; Osesp; Sala São Paulo; ethnography. 